\title{
Peran Kepemimpinan Dan Budaya Organisasi Dalam Meningkatkan Kinerja Pegawai Sektor Publik Di Kota
}

\author{
Sakinah AS, Anisah \\ Universitas Batanghari Jambi \\ Correspondence email: ina_ubr@yahoo.co.id
}

\begin{abstract}
This study aims to analyze the influence of leadership and organizational culture on the performance of public sector employees in the city of Jambi. The sample in this study is employees who work in the public sector in the city of Jambi. The data collection method used a questionnaire and analyzed using verification analysis, the analytical tool in this study is using Component Based SEM (Structural Equation Modeling), namely PLS (Partial Least Square). The results of this study will explain whether there is an influence from the main variables studied, namely the leadership, organizational culture and employee performance..
\end{abstract}

Keywords: Leadership; Organizational Culture; Employee Performance

\section{PENDAHULUAN}

Sumber daya yang dimiliki oleh organisasi dapat dikategorikan atas 4 tipe sumber daya yaitu fisik, finansial, manusia, dan teknologi. Dalam era keterbukaan, dan globalisasi, sumber daya manusia (SDM) yang ada dalam organisasi bukan hanya sekedar alat mencapai target organisasi semata tetapi SDM adalah aset organisasi yang harus dipelihara dan dikembangkan karena SDM dapat merupakan penentu keberhasilan aktifitas yang dilakukan.

Organisasi yang akan memperoleh keunggulan di masa depan adalah organisasi yang dapat menumbuhkan komitmen dari setiap orang, dan meningkatkan kapasitas belajar pada semua tingkat organisasi. Suatu organisasi meraih keberhasilan yang mengesankan, dan kompetitif justru karena cara mereka memperlakukan anggota mereka. Anggota organisasi tersebut senang datang ke tempat kerja dengan moral kuat, dan produktivitas yang lebih tinggi. Organisasi membutuhkan orang yang bersemangat, manajemen partisipatif, dan tim kerja yang terarah, dan terpadu di tempat kerja. Organisasi memaksimalkan potensi pegawai tergantung pada sisi manajemen yang lunak, bagaimana individu diperlakukan, diberi inspirasi dan tantangan untuk menghasilkan kinerja terbaik mereka, serta bimbingan oleh pimpinan untuk menjadikan performa pegawai yang luar biasa (Nelson, 2007). Mangkunegara (2007), menyatakan bahwa kinerja adalah hasil kerja secara kualitas dan kuantitas yang dicapai oleh seseorang pegawai dalam melaksanakan tugasnya sesuai dengan tanggung jawab yang diberikan kepadanya.

Setiap organisasi dalam berinteraksi dengan organisasi lain harus selalu peka terhadap aspirasi, keinginan, tuntutan, dan kebutuhan berbagai kelompok yang berinteraksi, hal ini merupakan tanggung jawab pimpinan dalam mengarahkan organisasinya. Martoyo (2000), mendefinisikan kepemimpinan adalah keseluruhan aktifitas dalam rangka mempengaruhi orang-orang agar mau bekerja sama untuk mencapai suatu tujuan yang memang diinginkan bersama untuk mempengaruhi kemauan orang lain untuk mencapai tujuan bersama. Para pimpinan sebagai salah satu pihak yang berkepentingan berada pada garis terdepan dalam mewujudkan perubahan suatu organisasi. Keberhasilan para pimpinan menanggapi perubahan yang terjadi memerlukan gaya manajerial yang sesuai dengan tuntutan perubahan. Dengan kepemimpinan yang baik maka organisasi dapat menciptakan suatu budaya yang dikenal dengan budaya organisasi yang dapat mengarahkan seluruh perilaku dan kegiatan organisasi pada visi dan misi organisasi.

Siagian (2004) memberikan definisi budaya organisasi yang berbunyi: "Nilai-nilai yang menjadi pedoman sumber daya manusia untuk menghadapi permasalahan eksternal dan usaha penyesuaian integrasi ke dalam perusahaan sehingga masing-masing anggota organisasi harus memahami nilai-nilai yang ada dan bagaimana mereka harus bertindak atau berperilaku. budaya organisasi umumnya menekankan pada pentingnya nilai-nilai yang dianut bersama dan ikatan kepercayaan serta pengaruhnya terhadap perilaku anggota organisasi.

Pada era otonomi daerah, negara memberikan ruang seluas-luasnya kepada daerah kabupaten dan kota dalam menentukan arah pembangunannya dengan memberikan wewenang penuh terhadap pengelolaan anggaran pendapatan belanja daerahnya masing-masing, sehingga tidak terjadinya tumpang tindih atau kontra terhadap visi dan misi negara Indonesia pada umumnya. Menyikapi kondisi ini maka setiap daerah yang merasa mampu dan memiliki SDA dan SDM yang memenuhi syarat administrasi berlomba-lomba untuk memisahkan diri dari daerah induknya dengan alasan otonomi, dan demi kemajuan pembangunan daerahnya.

Kota Jambi merupakan salah satu kota yang berada di provinsi Jambi. Untuk mencapai visi dan misi kota Jambi, maka seluruh sektor publik harus berrfokus untuk menyejahterakan masyarakat secara bertahap, baik dalam kebutuhan dasar maupun kebutuhan lainnya secara jasmani dan rohani, oleh karena itu dibutuhankan 
pegawai yang memiliki berdedikasi sehingga dapat mencapai kinerja organisasi.

Subjek pada penelitian ini yaitu pegawai yang bekerja pada sektor publik di Kota Jambi sedangkan objek yang diteliti yaitu mengenai kepemimpinan, budaya dan kinerja pegawai. Tujuan dari penelitian ini yaitu untuk melihat sejauh mana pengaruh kepemimpinan terhadap budaya dan kinerja pegawai sektor publik di kota Jambi

\section{Kepemimpinan}

Kepemimpinan diadopsi dari bahasa Inggris yaitu leadership. Leadership berasal dari akar kata to lead yaitu berupa kata kerja yang berarti memimpin. Lebih lanjut kepemimpinan tersebut dapat dipahami dengan to show the way to by going in advance. Dengan demikian memimpin merupakan suatu pekerjaan seseorang tentang bagaimana cara-cara untuk mengarahkan orang lain ( Utomo Warsito , 2006).

Kelangsungan hidup suatu organisasi dalam sejarah sangat dipengaruhi oleh pemimpinpemimpinnya. Hal yang dilakukan orang dalam organisasi mencerminkan perilaku pemimpinnya, orang cenderung mengikuti pemimpinnya. Pemimpin adalah orang yang membina dan menggerakkan seseorang atau sekelompok orang lain agar mereka bersedia, komit, dan setia melaksanakan tugas dan tanggung jawabnya di dalam mencapai tujuan perusahaan yang telah ditetapkan sebelumnya (Gorda, 2006).

Gorda (2006) mengatakan kepemimpinan adalah sifat atau karakter, atau cara seseorang di dalam upaya membina dan menggerakkan seseorang atau sekelompok orang agar mereka bersedia berkomitmen dan setia untuk melaksanakan kegiatan sesuai dengan tugas dan tanggung jawabnya untuk mewujudkan tujuan perusahaan yang telah ditetapkan sebelumnya.

Utomo, Warsito (2006), mengatakan di samping sebagai seni, kepemimpinan sering dipandang sebagai fokus dari kelompok, artinya pemimpin merupakan suatu subjek yang memotori kelompok. Pemimpin menjadi pusat perhatian, dan segala sumber yang menentukan segala sesuatu dari kelompok tersebut. Oleh karena itu seringkali pusat perhatian kelompok akan tertuju kepada pemimpin.

Dalam Usman (2008) Yulk, menyatakan beberapa definisi kepemimpinan :

1. Kepemimpinan adalah perilaku dari seorang individu yang memimpin aktifitas-aktifitas suatu kelompok ke suatu tujuan yang ingin dicapai bersama.

2. Kepemimpinan adalah pengaruh antar pribadi yang dijalankan dalam suatu situasi tertentu, serta diarahkan melalui proses komunikasi ke arah pencapaian satu atau beberapa tujuan tertentu.

3. Kepemimpinan adalah pembentukan awal serta pemeliharaan struktur dalam harapan dan interaksi.

4. Kepemimpinan adalah peningkatan pengaruh sedikit demi sedikit pada dan berada di atas kepatuhan mekanis terhadap pengarahan-pengarahan rutin organisasi.

5. Kepemimpinan adalah proses mempengaruhi aktivitas-aktivitas sebuah kelompok yang diorganisasi ke arah pencapaian tujuan.

6. Kepemimpinan adalah sebuah proses memberikan arti terhadap usaha kolektif dan yang mengakibatkan kesediaan untuk ,melakukan usaha yang diinginkan untuk mencapai sasaran.

7. Para pemimpin adalah mereka yang secara konsisten memberikan kontribusi yang efektif terhadap orde sosial, serta yang diharapkan dan dipersepsikan melakukannya.

Dalam Martoyo (2000) Miljus, mengatakan bahwa tanggung jawab para pemimpin adalah sebagai berikut:

1. Menentukan tujuan pelaksanaan kerja realistis (dalam artian kuantitas, kualitas, keamanan dan sebagainya).

2. Melengkapi para pegawai dengan sumber dana yang diperlukan untuk menjalankan tugasnya.

3. Mengkomunikasikan pada para pegawai tentang apa yang diharapkan dari mereka.

4. Memberikan susunan hadiah yang sepadan untuk mendorong prestasi.

5. Mendelegasikan wewenang apabila diperlukan dan mengundang partisipasi apabila memungkinkan.

6. Menghilangkan hambatan untuk pelaksanaan pekerjaan yang efektif.

7. Menilai pelaksanaan pekerjaan dan mengkomunikasikan hasilnya.

8. Menunjukkan perhatian kepada pegawai.

Menurut Gorda (2006), fungsi utama kepemimpinan dalam hubungannya dengan peningkatan aktivitas dan efisiensi perusahaan sebagai pembaharu (inovator), mensosialisasikan berbagai ide, gagasan, rencana dan program kerja perusahaan (komunikator), mendorong pegawai untuk melaksanakan tugas dan tanggung jawab secara ikhlas untuk mencapai tujuan perusahaan, membina, mendorong pegawai agar tetap memberikan sumbangan optimal kepada pencapaian tujuan organisasi (motivator) dan mengawasi atau mengendalikan berbagai aktivitas perusahaan ke arah efisiensi dan efektivitas (kontroler)

Dari kajian teori di atas dapat disimpulkan bahwa kepemimpinan adalah kemampuan yang dimiliki oleh seorang pemimpin, baik dalam pendekatan individu/ kelompok, pendekatan perilaku, pendekatan dalam proses manajemen yang dilakukan secara arif bijaksana, secara sukarela untuk mencapai tujuan organisasi yang telah ditetapkan bersama. Dalam kepemimpinan ini indikator yang akan dipakai adalah: perilaku pimpinan, kemampuan manajerial, pemberian motivasi.

Perilaku pemimpin, adalah tingkah laku pimpinan sebagai teladan bagi bawahan yang diukur dari persepsi pegawai tentang baik-buruknya perilaku pimpinan dalam memberikan arahan meliputi selalu memberikan arahan sebelum tugas diberikan, penjelasan yang diberikan 
mudah dipahami, memberikan solusi apabila ada masalah dalam pelaksanaan tugas

\section{Budaya}

Budaya organisasi mulai dipandang sebagai sesuatu hal yang memiliki peran penting dalam pengelolaan organisasi. Beberapa definisi "budaya organisasi" dikemukakan oleh para ahli yaitu Siagian (2004) memberikan definisi yang berbunyi: "Nilai-nilai yang menjadi pedoman sumber daya manusia untuk menghadapi permasalahan eksternal dan usaha penyesuaian integrasi ke dalam perusahaan sehingga masing-masing anggota organisasi harus memahami nilai-nilai yang ada dan bagaimana mereka harus bertindak atau berperilaku". Budaya Organisasi atau Budaya Perusahaan mempunyai pengertian sebagai aturan main yang ada di dalam perusahaan yang akan menjadi pegangan dari Sumber Daya Manusia (SDM)nya dalam menjalankan kewajibannya dan nilai-nilai untuk berperilaku di dalam perusahaan. (Atmosoeprapto, 2001) atau dapat juga dosebut sebagai budaya kerja

Budaya kerja memiliki beberapa karakteristik, seperti yang dikemukakan oleh Luthans (1992:563) sebagai berikut:

1. Peraturan-peraturan perilaku yang harus dipatuhi. Anggota organisasi saling berinteraksi dengan menggunakan tata cara, istilah, dan bahasa yang sama yang mencerminkan sikap yang baik dan saling menghormati.

2. Norma-norma. Suatu standar mengenai perilaku yang ditampilkan termasuk pedoman tentang apa saja yang harus dilakukan, yaitu tidak berlebih tetapi tidak juga kurang.

3. Nilai-nilai dan dominan. Adanya nilai-nilai terpenting dalam organisasi yang diharapan dianut oleh para anggotanya. Contohnya adalah mutu produk yang tinggi, tingkat absensi rendah, atau efisiensi yang tinggi.

4. Filosofi. Terdapat kebijakan atau peraturan yang mengarahkan organisasi tentang bagaimana memperlakukan karyawan dan / atau pelanggan.

5. Aturan-aturan. Terdapat pedoman yang harus ditaati jika bergabung dengan organisasi. Anggota baru harus mempelajarinya untuk dapat diterima didalam organisasi tersebut.

6. Iklim organisasi. Perasaan mengenai organisasi secara keseluruhan yang dicerminkan oleh tata letak fisik, cara para anggota berinteraksi, dan cara mereka berhubungan dengan pelanggan atau lingkungan diluar organisasi.

Uraian karakteristik budaya kerja yang lebih rinci diberikan oleh Charles Hampden-Turner (1990) sebagai berikut:

1. Budaya dibentuk oleh individu.

2. Budaya dapat menghasilkan keunggulan.

3. Budaya adalah suatu penguatan.
4. Penguatan-penguatan budaya cenderung untuk diperbanyak.

5. Budaya dapat diterima dan memiliki sudut pandang yang logis.

6. Budaya kerja membekali para anggotanya dengan kontinuitas dan identitas.

7. Budaya menyeimbangkan nilai-nilai yang saling berlawanan.

8. Budaya kerja adalah suatu sistem subernetik.

9. Budaya adalah suatu pola.

10.Budaya kerja adalah komunikasi.

11.Budaya kerja bersifat sinergis.

12.Budaya dapat dipelajari dan organisasi harus mempelajarinya.

Cunha dan Cooper (2001 : 22) juga menyatakan "organizational culture impact on financial performance, personal retention rates, and even on the success or failure of mergers and acquisitions", bahwa keberhasilan suatu perusahaan sangat ditentukan oleh keberhasilannya dalam menciptakan budaya kerja yang khas sebagai bagian dari rencana strategik mereka, karena budaya kerja yang baik akan berdampak terhadap kinerja keuangan, tingkat loyalitas pegawai, dan kesuksesan untuk bekerjasama. Budaya kerja yang efektif tersebut mencakup upah dan imbalan yang baik, komunikasi terbuka, penekanan pada mutu, keterlibatan pegawai dalam pembuatan keputusan, pembagian laba bagi pegawai, keadilan atau kesamaan status bagi pegawai, keamanan kerja, pelatihan, kebebasan berpendapat, penekanan pada inovasi, hubungan karyawanmanajemen yang baik, dan struktur administarsi yang sederhana.

Budaya organisasi perusahaan yang berorientasi global akan mempengaruhi dan dipengaruhi oleh budaya nasional dimana perusahaan itu beroperasi. Karena perusahaan global beroperasi di negara yang berbeda, maka mereka sebaiknya mengembangkan budaya organisasi yang berbeda dari budaya satu negara.

Budaya organisasi mengandung bauran, (1) nilainilai, (2) kepercayaan, (3) asumsi, (4) persepsi, (5) norma, (6) kekhasan dan (7) pola perilaku. Budaya dalam suatu organisasi membantu pekerja memberikan tanggapan atas ketidak pastian yang tidak bisa dihindari dan keruwetan dalam menyelesaikan suatu pekerjaan. Budaya organisasi adalah cara melihat dan berpikir mengenai perilaku dari dan dalam organisasi, suatu perpektif untuk memahami apa yang sesungguhnya sedang terjadi. Dalam kaitan ini, budaya organisasi ditujukan pada sekumpulan pokok pikiran yang mencoba menjelaskan dan memperkirakan bagaimana organisasi dan manusia bertindak dalam lingkungan yang berbeda.

Agar pekerjaan tetap menjadi lebih menyenangkan (enjoyable), Budaya Organisasi harus berkembang mengikuti perkembangan di dalam dan di luar Perusahaan. Oleh karena itu, perusahaan harus mampumengadaptasi perubahan-perubahan, perkembangan, dan inovasi yang terjadi di luar juga 
mampu mengintegrasikan perubahan dan perkembangan yang terjadi di dalam, sepeti nilai-nilai (values), profil karyawan, pengembangan Sumber Daya Manusia, dan lain-lain. Budaya Organisasi atau Budaya Perusahaan harus bersifat dinamis agar tetap bisa diterima oleh semua SDM-nya. Bila perlu diadakan re-engineering, antara lain melalui restrukturisasi dan refungsionalisasi organisasi (Atmosoeprapto, 2001).

Variabel budaya organisasi ini secara operasional diukur dengan menggunakan enam indikator yang diadopsi dari karakteristik budaya organisasi menurut Robbins (1990) yaitu: (1) Nilai-nilai organisasi, (2) Dukungan manajemen, (3) Sistem imbalan, (4) Toleransi dalam berbagi kesalahan sebagai peluang untuk belajar, (5) Orientasi pada rincian (detail) pekerjaan, (6) Orientasi pada tim

\section{METODE}

Penelitian ini adalah berjenis penelitian survei dengan tujuan eksplanatif. Teknik pengambilan sampel dalam penelitian ini yaitu menggunakan metode random sampling, dimana yang menjadi responden dalam penelitian ini adalah berjumlah 60 orang pegawai yang bekerja pada sektor publik di kota Jambi, tehnik pengumpulan data berupa kuesioner dan diolah serta dianalisis menggunakan Component Based SEM (Structural Equation Modeling) yaitu PLS (Partial Least Square).

\section{HASIL DAN PEMBAHASAN}

Karakteristik responden yang dijadikan sampel pada ini yakni sebanyak 63 orang pegawai perbankan, dimana jika dilihat dari usia dan tingkat pendidikan dapat dilihat pada tabel berikut :

Tabel 1. Karakteristik Responden Penelitian

\begin{tabular}{ccccc}
\hline No & \multicolumn{2}{c}{$\begin{array}{c}\text { Karakteristik } \\
\text { Responden }\end{array}$} & Frekuensi & Persentase \\
\hline \multirow{4}{*}{1} & \multirow{2}{*}{ Usia } & $30-30$ & 15 & $25 \%$ \\
& & $40-50$ & 28 & $47 \%$ \\
& & $>50$ & 5 & $20 \%$ \\
& & SMP & 2 & $3 \%$ \\
\multirow{2}{*}{2} & Tingkat & SMA & 7 & $11 \%$ \\
& Pendidikan & S1 & 47 & $78 \%$ \\
& & S2 & 4 & $7 \%$ \\
\hline
\end{tabular}

\section{Path Diagram}

Path Diagram adalah model dasar yang digunakan untuk menganalisis jalur untuk mengestimasi kekuatan dari hubungan-hubungan kausal, adapun path diagram dalam penelitian ini yaitu :

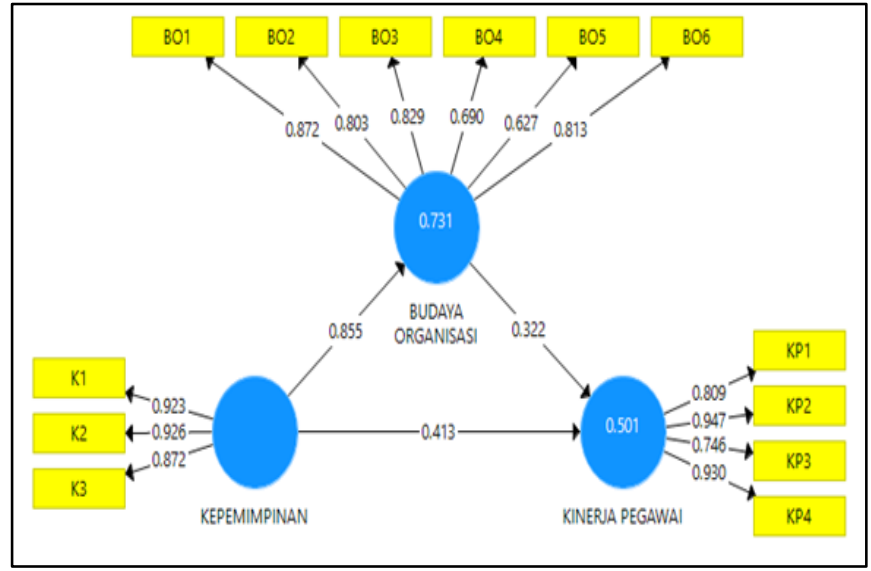

Gambar 1. Diagram Jalur Penellitian

\section{Outer Model}

Indikator dianggap valid jika memiliki nilai AVE diatas 0,5 atau memperlihatkan seluruh outer loading dimensi variabel memiliki nilai loading $>0,5$. Berikut adalah hasil uji validitas data menggunakan software smartPLS 3.0 :

Tabel 2. Uji Validitas dan Reliabilitas

\begin{tabular}{ccccc}
\hline Indikator & $\begin{array}{c}\text { Loading } \\
\text { Factor }\end{array}$ & AVE & $\begin{array}{c}\text { Composite } \\
\text { Reliability }\end{array}$ & $\begin{array}{c}\text { Cronbach } \\
\text { Alpha }\end{array}$ \\
\hline KP1 & 0,809 & & & \\
KP2 & 0,947 & & & \\
KP3 & 0,746 & 0,823 & 0,933 & 0,892 \\
KP4 & 0,930 & & & \\
\hline BO1 & 0,872 & & & \\
BO2 & 0,803 & & & 0.866 \\
BO3 & 0,829 & 0,604 & 0.900 & \\
BO4 & 0,690 & & & \\
BO5 & 0,627 & & & \\
BO6 & 0,813 & & & \\
\hline K1 & 0,923 & & & \\
K2 & 0,926 & 0,743 & 0.920 & \\
K3 & 0,872 & & & \\
\hline
\end{tabular}

Dari hasil pengujian validitas dan realibilitas pada Tabel 2 terlihat bahwa seluruh nilai outer loading indikator lebih besar dari 0,5 , nilai $A V E$ dari masing masing variabel lebih besar dari 0,5 , nilai cronbach alpha lebih dari 0,6, nilai composite reliablity seluruhnya lebih besar dai 0,6, maka dapat ditarik kesimpulan bahwa seluruh variabel dalam penelitian ini telah memenuhi syarat validitas dan reliabilitas.

\section{Inner Model}

Pengujian Goodness of Fit model struktural pada inner model menggunakan nilai predictive-relevance (Q2). Berikut hasil penghitungan predictive-relevance (Q2) model struktural adalah sebagai berikut: 
Sakinah AS dan Anisah, Peran Kepemimpinan Dan Budaya Organisasi Dalam Meningkatkan Kinerja Pegawai Sektor Publik Di Kota

Tabel 3. Nilai $R$ Square dan $Q$ Square

\begin{tabular}{lcc}
\hline \multicolumn{1}{c}{ Variabel } & $\mathrm{R}^{2}$ & $\mathrm{Q}^{2}$ \\
\hline Budaya Organisasi & 0,731 & 0,822 \\
Kinerja Pegawai & 0,501 & \\
\hline
\end{tabular}

$\mathrm{Q}^{2}$ menunjukkan bahwa nilai goodness of fit model struktural sebesar 0,82 mengindikasikan bahwa keragaman data yang dapat dijelaskan oleh model tersebut adalah sebesar $82 \%$

\section{Pengujian Hipotesis}

Hasil perhitungan menggunakan PLS didapatlah hasil dari pengaruh masing masing variabel adalah sebagai berikut:

Tabel 4. Pengaruh Variabel Penelitian

\begin{tabular}{lccccc}
\hline & Hypothesis & Total Effect & $P$ - value & Informasi \\
\hline Kepemimpinan & $\rightarrow$ Budaya Organisasi & 0,855 & 0,039 & Signifikan \\
Kepemimpinan & $\rightarrow$ Kinerja Pegawai & 0,688 & 0,000 & Signifikan \\
Budaya Organisasi & $\rightarrow$ Kinerja Pegawai & 0,322 & 0,042 & Signifikan \\
\hline
\end{tabular}

Berdasarkan tabel 4. terlihat bahwa nilai pengaruh kepemimpinan terhadap budaya organsasi adalah sebesar 0,845 dengan $P$ values sebesar 0,039 yaitu dibawah 0,05 , hal ini membuktikan bahwa kepemimpinan berpengaruh positif dan signifikan terhadap terhadap budaya organisasi. Berdasarkan tabel 4. terlihat bahwa nilai pengaruh kepemimpinan terhadap kinerja pegawai adalah sebesar 0,688 dengan $P$ values sebesar 0,000 yaitu dibawah 0,05 , hal ini membuktikan bahwa kepemimpinan berpengaruh positif dan signifikan terhadap terhadap kinerja pegawai. Berdasarkan tabel 4 . terlihat bahwa nilai pengaruh budaya organisasi terhadap kinerja pegawai adalah sebesar 0,322 dengan $P$ values sebesar 0,042 yaitu dibawah 0,05 , hal ini membuktikan bahwa budaya organisasi berpengaruh positif dan signifikan terhadap terhadap kinerja pegawai

Pada pengujian outer model terlihat bahwa indikator yang memiliki nilai paling tinggi pada variabel kepimpinan yaitu K1 (perilaku pemimpin), hal ini menunjukkan bahwa perilaku pemimpin merupakan faktor yang paling berpengaruh terhadap tingkat kepemimpinan pada sektor publik. Pada pengujian outer model terlihat bahwa indikator yang memiliki nilai paling tinggi pada variabel budaya organisasi yaitu BO1 (nilai nilai organisasi), hal ini menunjukkan bahwa nilai nilai organisasi merupakan faktor yang paling berpengaruh terhadap tingkat budaya organisasi pada sektor publik. Pada pengujian outer model terlihat bahwa indikator yang memiliki nilai paling tinggi pada variabel kinerja pegawai yaitu KP2 (kuantitas), hal ini menunjukkan bahwa kuantitas merupakan faktor yang paling berpengaruh terhadap tingkat kinerja pegawai pada sektor publik

dari hasil analisis inner model didapat bahwa terdapat pengaruh yang positif dan signifikan dari kepemimpinan terhadap budaya organisasi dan kinerja pegawai dan terdapat pengaruh yang positif dan signifikan dari budaya organisasi terhadap kinerja pegawai, hal ini sejalan dengan penelitian penelitian sebelumnya yang dijadikan landasan dalam penelitian ini, semakin tinggi tingkat kepemimpinan pada sektor publik maka akan semakin meningkat pula budaya organisasi dan semakin meningkat budaya organisasi akan berdampak terhadap peningkatan kinerja pegawai sektor publik.

\section{SIMPULAN}

Dari uraian hasil penelitian dan pembahasan penelitian sebagaimana yang diuraikan pada bab sebelumnya, maka dapat ditarik beberapa kesimpulan, kepemimpinan berpengaruh positif dan signifikan terhadap budaya organsiasi, kepemimpinan berpengaruh positif dan signifikan terhadap kienrja pegawai, budaya organisasi berpengaruh positif dan signifikan terhadap kinerja pegawai. Penelitian ini memiliki batasan dengan sampel yang cukup kecil sehingga sangat disarankan bagi peneliti peneliti selanjutnya yang meneliti dengan topik yang sama untuk meneliti dengan sampel yang lebih besar agar dapat menarik kesimpulan yang lebih kuat dari penelitian inii.

\section{DAFTAR PUSTAKA}

Atmosoeprapto, Kisdarto. 2001. Produktifitas Aktualisasi Budaya. Jakarta : Alex Media Komputindo

Dessler, Gary. 2004, Management. Terjemahan Benyamin Molan, Jakarta: PT. Prehalindo

Gorda, I Gusti Ngurah. 2006. Manajemen Sumber Daya Manusia. Denpasar: Astrabrata Bali Denpasar dan STIE Satya Dharma Singaraja.

Handoko, T.Hani, 2009, Manajemen Sumber Daya Manusia, BP- FE UGM, Yogyakarta

Mangkunegara, Anwar Prabu, 2000, Manajemen Sumber Daya Manusia, PT. Remaja Rosda Karya, Bandung

Mangkunegara, Anwar Prabu. 2007. Evaluasi Kinerja SDM. Bandung : PT.Refika Aditama

Martoyo, Susilo. 2000. Manajemen Sumber Daya Manusia. Yogyakarta : BPFE.

Manullang, S, 2001, Manajemen Sumber Daya Manusia, Penerbit LP FE-UGM, Yogyakarta

Nelson, Bob. 2007. Seribu satu cara untuk menjadikan karyawan bersemangat. Batam Centre. Karisma Publishing Group.

Ruky.S. Ahmad 2001 Sistem Manajemen Kinerja. Jakarta: Gramedia Pustaka Utama, 2001 
Sakinah AS dan Anisah, Peran Kepemimpinan Dan Budaya Organisasi Dalam Meningkatkan Kinerja Pegawai Sektor Publik Di Kota

Simamora, Henry. 2004. Manajemen Sumber Daya Manusia. Yogyakarta : STIE YKPN

Siagian, Sondang P. 2002, Pengembangan Sumber Daya Insani, Gunung Agung, Jakarta

Siagian, Sondang P. 2004. Manajemen Sumber Daya Manusia. Yogyakarta : STIE YKPN.

Sedarmayanti, 2001. Restrukturisasi dan Pemberdayaan Organisasi Untuk MenghadapDinamika Perubahan Lingkungan, Mandar Maju, Bandung

Utomo , Warsito. 2006. Administrasi Publik Baru Indonesia : Perubahan Paradigma dari Administrasi Negara ke Administrasi Publik. Yogyakarta : Pustaka Pelajar.

Usman, Husaini . 2008 . Manajemen; Teori, Praktik, dan Riset Pendidikan, Edisi Kedua. Jakarta : PT. Bumi Aksara

Wursanto IG, 2001, Manajemen Kepegawaian, Penerbit LKPN, Jakarta 